\title{
LEGAL RESEARCH: TECHNIQUES AND IDEAS
}

\author{
E P Ellinger* and KJ Keith**
}

This paper was prepared for the conference of New Zealand University Law Teachers held at Massey University in November 1977. Though the authors here make no special claims of originality or great insight, the many ideas developed, particularly when taken together with Professor Campbell's trenchant piece on legal writing and John Thomas' more recent article on legal education (both reprinted in this volume), which stresses the relationship between. teaching and research, will be of value to the increasing numbers of lawyers engaged in research.

\section{INTRODUCTION}

Laymen tend to believe that good ideas just "come" to an academic author, who possesses a "holy spark". To refute this view is just as difficult as it is to establish that new ideas are, invariably, the outcome of meticulous work. It is impossible to generalise. Undoubtedly, inspiration plays an important role in the selection by an author of a fruitful area for research and is indispensable for recognising and developing a good idea. In its absence, a fascinating topic may receive a mundane and boring treatment. It is, however, fallacious to underestimate the hard work which is frequently hidden behind the polished aces of a well written paper or book. An old authority, an obsolete statute or a forgotten text written by an anonymous lawyer of days gone by is, in many cases, the source which guides a research worker to a path leading to a creative and original piece of work or which inspires in him a new conceptual approach to a legal problem. It is undeniable that a certain element of luck is usually present in such a discovery. The research worker, however, needs to have the intuition to recognise the importance of his find. He must, also, be capable of undertaking the hard and tedious spadework which, unearths it. Thus, it seems likely that, in the majority of cases, inspiration and hard work are complementary. If a book or article breaks

* Sir John Barry Professor of Law, Monash University; formerly Professor of Law at Victoria University of Wellington. The paper was first published at (1979) 10 VUWLR 1.

** Professor of Law and Dean of the Faculty of Law, Victoria University of Wellington. 
new ground, one may, more often than not, assume that the author has both a sound research technique and the gift of original thinking.

It would be tempting to investigate the meaning of inspiration and the existence of roads leading to it. But such an enquiry is better left to the psychologist. Lawyers are well advised to focus on a related question, namely on the connection between research techniques and ideas and on the manner in which the former trigger off the latter.

These are the tasks which we have set ourselves in this paper. Its first section discusses specific methods of research respecting the study of case law and of statutes. The second section concerns the relationship between research and teaching and how the combination of the two is conducive to the production of original ideas. A particular aspect of that is the teaching of small groups at honours and masters level. In the final part of the paper we discuss the value of research oriented work to legislative law reform and to the development of the Common Law.

\section{RESEARCH TECHNIQUES}

\section{A Observation on the Reading of Case Law}

\section{Slower reading?}

Speed is one of the idols of our time. Planes are made to fly faster than the speed of sound. Computers are constructed in order to cut short the time required for calculations. Even the number of days required for clearing a cheque is, today shorter than it was ten years ago. It is not surprising that this trend to speed has led to the publication of books which advocate a more efficient, or quick, mode of reading. Undoubtedly, there is much to be said for this approach in certain areas of the every day life of a lawyer. It requires an inordinate degree of patience and of enthusiasm for the mundane to read word by word a ten page mortgage or a set of company's articles blessed with the absence of any punctuation.

We are, however, not convinced that "fast reading," produces the best results in studying and in assimilating case law. It may of course, be adequate for the mere purpose of getting a general impression of a new case. But this can be done just as efficiently, and in even less time, by reading the headnote or a note in a legal periodical. "Fast reading" may, however, be dangerous when a case is being studied for research purposes or in order to produce an opinion. First, a speedy reader, may lead to an inaccurate comprehension of the ratio decidendi of the case. Secondly, it may preclude the reader from appreciating the finer nuances of a case or of a point emerging from between the lines. The recent decision of the Court of Appeal in Walpole and Patterson $v$ National Bank of New Zealand ${ }^{1}$ is a classic example of this point. 
This case concerned the liability of a bank that paid a number of cheques which had been forged or irregularly drawn by the plaintiffs' unscrupulous employee over a number of years. The court followed the established case law highlighted by, Greenwoood $v$ Martins $B a n k,{ }^{2}$ and, accordingly, rejected the pleas of estoppel and of the customer's negligence. The only interesting aspect of the case was that Richmond J expressed his surprise that the bank had not sued the crooked employee in deceit or in negligence, joining the plaintiffs on the ground of vicarious liability. We suspect that a person, who reads this case in the modem speedy method, may overlook the significance of this observation and the possibilities opened by bringing this type of counter-claim. This is not because the modern reading method would prevent the reader from noticing the relevant lines. The danger, rather, is that, in his hurry, he may overlook the revolutionary nature of what may, at first glance, appear to be an insignificant dictum. A slower reader, on the other hand, may stop for a moment in order to ask himself: "Why on earth was this point not made before?" The answer emerged when one notes that a significant number of the earlier relevant cases were decided before the House of Lords held that an employer could be vicariously liable for an act of the employee, even though the act was contrary to the employer's interests. ${ }^{3}$

It would be wrong to pretend that every slow reader would discern the significance of the point in question. Indeed, this is the very type of situation where an appropriate research technique (the meticulous reading of cases) has to be augmented by what we are calling - in this paper - inspiration. The point we are trying to make is that the wrong technique, of an unduly fast reading of cases, may prevent an inspired lawyer from spotting the new trail.

\section{Comparing different reports of a case}

Many a good idea is born when one compares different reports of a given case.

This notion, of course, is not new. One thinks of it mainly in respect of older cases, decided in the 18th and in the first half of the 19th century, when law reporting was far from accurate. An instance, recently spotted by one of us, is the decision of Lord Eldon in Ex parte Waring," concerning the "rule of the double bankruptcy of the drawer and of the acceptor of a bill of exchange". The ratio commonly attributed to this decision is that, in

2 [1933] AC 51. As regards the general body of authorities in point, see A G Guest (ed, Chitty on the Law of Contract (24 ed, London, 1977) ss 2428, 2554.

3 As settled in Lloyd $v$ Grace Smith \& Co [1912] AC 716. The cases relevant to the issue of banking, which were decided before this case, are Young $v$ Grote (1827) 4 Bing 253 and Scholfield $v$ Londesborough [1896] AC 514. Although the leading case of London Joint Stock Bank v MacMillan [1918] AC 777 was decided after the decision in Lloyd's case the significance of the ratio in the latter was overlooked in the former.

4 (1815) 19 Ves Jun 325; 2 Rose 182; 2 Glyn \& Jameson 404. 
cases of this type, the holder of the bill has the right to be satisfied out of the proceeds of securities given by the drawer to the acceptor, even if these securities are not held by the acceptor as the holder's trustee. ${ }^{5}$ The best known report of this case - in Vesey junior supports this unsatisfactory conclusion, which places bill holders in the class of secured creditors, although they have neither bargained for nor are aware of the existence of the securities in question.

A study of the other reports of Ex parte Waring demonstrates that Lord Eldon had no intention of prescribing a general rule to such an effect. His decision was based on the special facts of the case and had the object of releasing the acceptor's estate from any liability to the drawer so as to enable the acceptor's creditors to be satisfied out of the balance of the securities in question. The decision, in other words, was based on the state of the accounts between the acceptor and the drawer. Unfortunately, the report in Vesey junior was the only one consulted by Lord Cranworth in a subsequent case, ${ }^{6}$ in which the accounts were in a different state and in which the acceptor's creditors stood to gain no benefit from the release of the securities from any right or lien of the drawer. While Lord Cranworth expressed dissatisfaction with the general rule as stated in the defective report, he adopted it out of respect for Lord Eldon. Later judges followed his example. ${ }^{7}$ English law was marred by an unsatisfactory principle because the least accurate account of a case was included in the most accessible set of reports.

The technique of comparing reports can occasionally bring a bonus in respect of modern cases. Woods $v$ Martins Bank ${ }^{8}$ shows that judges do tend, from time to time, to add a new point when revising an oral judgment, or a judgment in typescript, for publication in the official set of reports. The case, decided in 1959, involved an action by a young man against a bank, brought in respect of advice on investments given by the manager of a branch. An action in tort was ruled out by Le Lievre $v$ Gould ${ }^{9}$ and Candler $v$ Crane Christmas $\&$ Co, ${ }^{10}$ which reigned supreme at that time. The action was, therefore, brought in contract, but was fraught with difficulties as the advice had been given to the young man before he opened his account with the bank. Originally, Salmon J got over this difficultly by deciding that the

5 For an analysis of the topic, see Ellinger "Securitibank's Collapse and the Commercial Bills Market of New Zealand" (1978) 20 Malaya L Rev 84, 95 et seq.

6 Powles $v$ Hargreaves (1833) 17 Jur 612, affirmed ibid, 1083.

7 With the notable exception of Royal Bank of Scotland $v$ Commercial Bank of Scotland (1882) 7 App Cas, 366. And see Ellinger, op cit.

8 [1959] 1 QB 55.

9 [1893] 1 QB 491.

10 [1951] 2 KB 164. 
advice was reiterated, by implication, when the account was eventually approved for opening. The plaintiff was therefore entitled to recover on the ground of a breach of a contractual duty of care owed to him as customer. When revising his judgment for inclusion in the official reports, his Lordship added a further ground. He held that even before the bank agreed to open the plaintiff's account, it had assumed towards him the duties resulting from a fiduciary relationship, created when the branch manager undertook to advise the plaintiff about the mode of investing his funds.

The addition of the fiduciary relationship ground to the judgment after its delivery in court was significant as it disclosed the policy motivation of the learned judge. It indicated that he wanted to mitigate the effect of the rule in Candler's case, which precluded the institution of actions in tort in respect of pecuniary loss resulting from a negligent, noncontractual, statement. Obviously, Salmon J saw the fiduciary relationship as a device for paving the way for the abrogation of the general rule. To an imaginative thinker this might have foreshadowed the decision in Hedley Byrne \& Co $v$ Heller \& Partners. ${ }^{11}$ It might have encouraged him to find arguments throwing doubts on the soundness of the rule in Candler's case. Counsel in Hedley Byme adopted this very course.

A lesser example of second or further thoughts - involving a response to comments made on the judgment after its delivery - is to be found in a note at the end of the Queens Bench Report (but not in the Weekly Law Reports) of the Crossman Diaries case. ${ }^{12}$ Widge LCJ made it clear that the general argument in the body of his judgment might apply not just to Cabinet and ministerial discussions but also to discussions with officials; the original judgment had seemed to imply that the general argument was irrelevant to those discussions.

A slightly different example arises in respect of a case, one report of which has been abridged (especially by the omission of a passage) and one of which has not been. The reading of the full judgments in the oft cited Court of Appeal case of Merchandise Transport Ltd $v$ British Transport Commission ${ }^{13}$ and in a companion and closely related case ${ }^{14}$ as set out in the Weekly Law Reports, the All England Reports and the Traffic Cases gives a quite different impression from that obtained from the shortened Queens Bench report.

It would, of course, be unrealistic to suggest that all reports of a case need be compared in respect of every authority cited in a paper or in an opinion. It is, however, a sound policy

11 [1964] AC 465.

12 Attorney-General v Jonathan Cape Ltd [1976] 3 QB 752, 772. [1962] 2 QB 173, [1961] 3 WLR 1358, [1961] 3 All ER 495, 32 Traf Cas 19.

14 Amold Transport Rochester Ltd $v$ British Transport Commission reported in last three reports listed in n 13. 
in respect of leading cases. Moreover, such a comparison may, occasionally, explain a specific passage which seems obscure or out of place. Here, again, intuition or inspiration becomes an important factor.

The understanding of a judgment may also be assisted by reference to the arguments made in a case (but generally provided - if at all - only by the official reports). Police $v$ Lee ${ }^{15}$ is a recent example of the court itself getting such assistance. The paucity of the argument on the void-voidable issue in Ridge $v$ Baldwin ${ }^{16}$ may help explain the shallowness and confusion of the discussion of that issue in the judgments (especially when compared with the brilliant treatment of the major issue). And, turning to quite another field, many judgments, opinions and orders of the International Court cannot be properly understood without recourse to the written and oral pleadings: that is particularly true of the orders of the court for they are usually very briefly reasoned. It is, we think, a serious matter that we no longer have this aid nor even a list of cases cited in argument in the New Zealand Law Reports.

\section{Reading case law in its historical context}

Certain textbooks continue to treat Common Law subjects on the basis that prevailing case law is a homogenous and contemporaneous body. A decision which remains binding receives a treatment which does not take into account whether it stems from the 18th, the 19 th or the 20th century. We do not propose to challenge this approach in itself. Nevertheless, the historical background of a case is of considerable importance as it can shed light on the true grounds of, and on the policy related to, the decision. Occasionally, that background may also suggest good reasons for distinguishing the case or for treating it as obsolete or as obscure.

The setting aside by courts of Equity of bargains made with expectant heirs furnishes a good illustration. It seems quite clear that one reason for the enthusiasm with which Equity saved remaindermen from the consequences of bargains which, at their inception, may have been perfectly fair and reasonable was the wish to protect the estates of the landed classes. It was feared that such bargains would have a "pernicious effect". ${ }^{17}$ One wonders whether or not this case law, had it not been the subject of legislative reforms, would be followed in the 20th century. Would not the ulterior motive for these decisions have induced a modem court to refuse to interfere with such a bargain where it was fair and reasonable? Such a

15 [1973] 1 NZLR 470, 477.

16 [1964] AC 40. See the note of the argument at 54-55 and 59.

17 Gwyne $v$ Heaton (1778) 1 Bro CC 1, 9; and see Osmond v Fitzroy (1731) 3 P Wms 129; Chesterfield (Earl of) $v$ Janssen (1750) 2 Ves Sen 125; Aylesford (Earl of) $v$ Morris (1873) LR 8 Ch App 484. 
change in approach could have been easily supported by a return to some 17 th century cases! ${ }^{18}$

It was, of course, just such a leap back that helped Lord Reid (who had in turn been assisted in that leap by Professors Wade and de $S^{1} \mathrm{mith}^{19}$ ) to put the cases of the preceding thirty to forty years into perspective and to resurrect basic principles in Ridge $v$ Baldwin. ${ }^{20}$ Even Lord Radcliffe was shown to have fallen into error by not taking a long view of the law. 21

Another example in point is to be found in cases concerning actions in conversion brought by true owners of cheques against bankers who collect them under instructions from persons without a title. A statutory defence, available since 1876, is applicable only where the banker has acted "without negligence". The exact meaning of this phrase has, however, changed considerably from time to time. Thus, in 1933 a bank was held negligent where it collected for the credit of the account of the wife of a stockbroker's clerk, a cheque which her husband had stolen from his employers. ${ }^{22}$ The House of Lords was of the view that when a bank opened an account in the name of a married woman, it ought to investigate who were her husband's employers. It is hard to believe that such a strict view about the collecting bank's duty of care would be taken nowadays. Indeed, in a case decided in 1963, the Court of Appeal thought that a bank was not under an obligation to trace the changes in the employment of a customer, who was a company's director. ${ }^{23}$ In another recent case it was observed that whether or not a banker was negligent in the collection of a cheque depended primarily on prevailing banking practice. ${ }^{24}$ This case recognised, implicitly, that there could be changes in the nature of the duty of care imposed on collecting bankers. It is clear that this approach is to be encouraged. It would be unrealistic to expect a giant banking chain, like the leading banks of England or of New Zealand, to be as familiar with the business of each of its customers as were banks that operated in a period in which the maintenance of a bank account was the privilege of the well off.

18 Ardglasse (Earl of) $v$ Muschamp (1684) 1 Vern 237; Wiseman $v$ Beake (1690) 2 Vern 122.

19 See the writing by Wade referred to in argument in [1964] AC at 62 and ch 4 of de Smith Judicial Review of Administrative Action (London, 1959).

20 Supra $n 16$.

21 In Nakkuda Ali v Jayaratne [1951] AC 66, PC, "no case older than 1911 was cited . . on this question, and this question was only one of several difficult questions which were argued and decided" ([1964] AC at 78). 
These examples indicate that the reading of a case with a view to its historical background may on occasions aid in assessing its importance in a different era.

Undoubtedly, neither this suggestion, nor the ones made in the previous pages, are innovative. Neither are they meant to be exhaustive suggestions for improving research techniques. Thus, the reading of cases in their political and sociological context is, undoubtedly, another useful approach to legal problems: the waxing and waning of the presumptions in the particular area relating to property rights and to freedom of commerce can be related to broad politico-economic trends, as can changes in the force of the presumptions relating to the validity of subordinate legislation. ${ }^{25}$

\section{B Analysis of Statutory Law}

\section{The historical approach}

The historical approach is just as important in the comprehension of statutory law as it is in the study of case law. Any lawyer who hopes to comprehend the Companies Act 1955 or the Chattels Transfer Act 1924 without studying their historical backgrounds is setting himself an impossible task. The same goes for the Continental codes, which become clear only when read with an eye to the period in which they were enacted.

There are two reasons for the importance of the historical background of statutory law. First, very few pieces of legislation are original in the sense of being pure innovations of a skilled draftsman. In the majority of cases he consults and adapts earlier statutes or makes use of principles laid down or proposed in decided cases. On the Continent, the draftsmen may, even, resort to suggestions made in treatises of professors of law. ${ }^{26}$ Secondly, laws are not made in a vacuum. They are passed in order to meet some needs of society. While they may not always reflect the true wishes of the people, or even of the ruling group, they reflect, nevertheless, the historical and political spirit of the day. The usury law of Henry VIII illustrates the point. ${ }^{27}$ In essence, the law permitted the charging of a rate of up to ten percent per annum on loans and on mortgages. Whether or not the monarch, who purported to be a theologian, was genuinely in favour of relaxing the strict biblical prohibition on

25 Compare the emphasis by Callan J, when striking down the first import control regulations, on the economic rights of the individual with the emphasis by the Court of Appeal, when upholding wage control regulations, on the power of the state to control the economy, FE Jackson and Co Ltd $v$ Collector of Customs [1939] NZLR 682, 709, 735, 739 and NZ Shop Employees' Industrial Assn of Workers $v$ Attorney-General [1976] 2 NZLR 521 (CA).

26 This is particularly the case in German law; so the German Civil Code was much influenced by, and bears the stamp of, Windscheid's Lehrbuch des Pandekten. The edition consulted by the Commission which drafted the Code was the eighth. 
usury is questionable. He did, however, need finance and the only way of obtaining substantial loans was to legalise a certain rate of interest. The merchants of London were not opposed to this Act, as it saved them the need to resort to notorious and questionable evasion techniques, ${ }^{28}$ which could be dangerous when employed in dealings with an unpredictable ruler.

There is at least one significant difference between reading cases in their historical context and the same technique when applied to the study of a statute. A statute is more likely to reflect the spirit of the day than a legal decision. Thus, many modern cases concerning the law of contract manifest the laissez-faire spirit which is by no means a reflection of current economic and sociological philosophy. ${ }^{29}$ Similarly, cases concerning restitution are, occasionally, fully understandable only by tracing earlier decisions in point right to the 18 th century. ${ }^{30}$ It is undeniable that the same applies in the case of some statutes which are the end result of the consolidation or of the revision of earlier Acts. Thus, some of the provisions of the Insolvency Act 1967 can be traced back to an Act passed by Queen Elizabeth I. ${ }^{31}$ Similarly, many provisions of the Bills of Exchange Act, 1882 have their origin in case law of earlier centuries. ${ }^{32}$ For the most part, however, many modern Acts, such as statutes in the field of matrimonial law, ${ }^{33}$ reflect the spirit of the 20 th century.

We believe that the study of statutory law from an historical point of view is a fruitful mode of research not only when applied in the more traditional Common Law and commercial law fields but also in public law subjects. An historical approach to much constitutional legislation is, of course, indispensable - and not just in research but in teaching as well. Thus the growth of the power of the New Zealand Parliament cannot be measured solely by a reading of the legislation of $1852,1857,1865$.... To be understood, the

28 These are reflected in the Preamble to the Act in question and in s 2, which prohibited the sale of goods with an agreement to re-purchase them for a lower price within a period of three months.

29 Reflected far more clearly in statutes such as the Consumer Credit Act 1974 (UK), which abrogates the freedom of contract of finance houses in transactions with consumers.

30 For an interesting illustration, see National Westminster Bank Ltd v Barclays Bank Intermational Ltd. [1975] QB 654, in which Kerr J found it necessary to study a body of case law, commencing with Lord Mansfield's decision in Price $v$ Neal (1762) 3 Burr 1354 to determine the current legal position.

31 The Act against Fraudulent Deeds Alienation 13 Eliz, c 5 (6 Pickering 268), which forms the basis of the provision concerning fraudulent preferences in $s 54$ of the Insolvency Act 1967.

32 Note that Sir McKenzie Chalmers published the first edition of his book on bills of exchange in 1878, a few years before he embarked on the task of consolidating the law of negotiable instruments.

33 See, for example, the title to the Matrimonial Property Act 1976 ("to recognize the equal contributions of husband and wife to the marriage partnership; ....".). 
legislation must be seen in broader context. ${ }^{34}$ The importance of the historical and political background to the interpretation and understanding of more recent constitutional legislation is neatly demonstrated by a comparison of Victorian and Alberta decisions on the Ombudsman ${ }^{35}$ The Canadian court was much more sensitive to the mischief the office was designed to alleviate: it referred to the development of the idea in the province. ${ }^{36}$ The Australian judges approach their task in a much more wooden, literal way. ${ }^{37}$

\section{Discovering the political background}

The historical background of an Act tends, frequently, to reflect the political climate of its day. Usury laws are, again, illuminating. The firm opposition in medieval Europe to legalising the charging of interest on loans reflected the overwhelming power of the church. only a strong monarch, like Henry VIII, could, in the 16th century, take the first open step, in England, for removing this antiquated prohibition. ${ }^{38}$ The removal of all controls on usury, in 1854, reflected the secular laissez-faire spirit, which was dominant throughout most of the 19th century. ${ }^{39}$ The re-introduction of controls with the passing of the Moneylenders Act in 1900 amounted to a recognition by the state of the need for some curbing of the total freedom of bargaining in the field of credit and of lending. The overhaul of the entire law respecting consumer credit, in 1974, was a further step in the direction of the paternalistic protection of the average citizen by the state. ${ }^{40}$

The techniques for discovering the background of an Act are too well known to be discussed in detail. The preamble, a marginal note, the explanatory note to the Bill and the

34 See, for example, the excellent essays in J C Beaglehole (ed) New Zealand and the Statute of Westminster (Wellington, 1944).

35 See especially Glenister $v$ Dillon [1976] VR 550, F C, and Re Alberta Ombudsman Act (1970) 10 DLR (3d) 47.

3610 DLR (3d) at 51-58.

37 So Gillard J at 556-558 proceeded on the basis that there was a single, true meaning of the word "administration", a meaning which could be derived from such disparate sources as Sir William Holdworth's usage in arranging his historical work and as the drafting of the League of Nations mandate for New Guinea.

38 Supra $n 27$.

39 The Act to Repeal the Laws Relating to Usury and to the Enrolment of Annuities (17 \& 18 Vict, c 90), the philosophy of which was strongly influenced by Bentham's The Defence of Usury. The effect of this unfortunate measure is highlighted in the report of the Select Committee of the House of Commons of 1898 (Great Britain Parliament. House of Commons. Parliamentary Papers, 1898: 260), which led to the enactment of the Money-lenders Act, 1900.

40 The Consumer Credit Act, 1974, which reflects the views of the Report of the Crowther Committee Consumer Credit (1971 Cmnd 4596). 
parliamentary debates are obvious and useful means. Reports of learned committees are, likewise, of assistance where available. The more intriguing problem is to discover the specific background of an Act where such tools are absent or fail to shed light on some of its aspects. Case law immediately preceding the Act in question can occasionally provide the answer. Thus, a person who reads the Promissory Notes Act passed in $1704,{ }^{41}$ during the reign of Queen Anne, is likely to be puzzled by the fact that the statute declared that promissory notes made within a period of three years of its enactment would be valid and binding. Why, one is inclined to think, did the legislature choose to introduce such a limitation of time? A review of case law decided in the 17th century tends to exacerbate the problem: promissory notes - or instruments very similar to them - were treated as a species of bills of exchange without any demur. ${ }^{42}$ The answer to the puzzle is provided by a number of cases decided by Sir John Holt in the first three years of the 18th century. ${ }^{43}$ For some strange reason - presumably one connected with the wish to maintain the purity of the Common Law - that great and otherwise liberal judge refused to recognise what appeared in his eyes to be a novel form of a negotiable instrument. Moreover, he went so far as to remonstrate with leading merchants against the use of such inelegant instruments. ${ }^{44}$ The effect of the Act of Queen Anne was to overrule his decisions. Presumably, the fixing of a probationary period of three years was a device for saving the face or the Chief Justice of the Queen's Bench. From a political point of view, however, the Act may be regarded as constituting a compromise between the policy advocated by the Bench and the needs of the City.

Modern examples are not hard to find. An interesting one was the enactment in 1922 of the provision, now appearing as section 19 of the Chattels Transfer Act 1924, which attempted to safeguard the rights of a bona fide purchaser who had acquired a chattel covered by an unregistered mortgage. The original provision was drafted in a hurry and passed by Parliament with hardly any discussion shortly after Salmond J, in two decisions, pointed out the hazards of the failure to include such a provision in the 1908 Act. ${ }^{45}$ There is, however, an interesting contrast between the history of the Act of Queen Anne and the passing of section 19. In the former case, an Act was passed with the object of removing an obstacle to commercial practice resulting from an error in judgment of a formidable judge; in

41 The Promissory Notes Act, 3 \& 4 Anne, c 9.

42

See, for example, Williams $v$ Williams (1693) Carth 269.

Potter $v$ Pearson (1702) 2 Ld Ray 759; Clerke v Martin (1702) 2 Ld Ray 757; Buller v Crips (1703) 6 Mod 29.

See Buller $v$ Cribs (1703) 6 Mod 29.

Nash v Barnes [1922] NZLR 303, 305; $R$ v Buckland \& Sons Ltd [1922] NZLR 683, 688. 
the second example an observation of an equally distinguished judge induced the legislature to remedy a defect in an Act resulting from the draftsman's oversight.

Legislation increasingly has a relevant international background for much of it is enacted to give effect to the treaty obligations accepted by the Government towards other countries. The practical importance of an understanding and knowledge of that wider political context is evidenced by the increasing willingness of the courts to take account of relevant international instruments when construing the legislation. ${ }^{46}$

\section{The Comparative Approach}

A particularly useful source of ideas is the comparative approach to legal problems. This is not to say that every topic lends itself to such treatment or, indeed, that every piece of comparative research is likely to produce good results. A mere comparison of solutions found in different legal systems to a given problem can be both dull and tedious, particularly where the author's sole object is to note similarities and dissimilarities. The instances in which comparative research pays a bonus tend to occur where it is given one of the main functions which can be usefully served by it and which are three in number. First, comparative research can throw doubt the usefulness of strongly entrenched views. Secondly, it may suggest a suitable solution to legal problems. Thirdly, a comparative study tends to aid in assembling which principles, applicable in the field concerned, are fundạmental and which are secondary.

That the examination of the solution to a given legal problem in a foreign jurisdiction might cast doubts on what could otherwise appear unquestionable is easily demonstrated, Gower's Modern Company Law is a good example. Many lawyers, who grew up with earlier texts on the subject, must have been surprised to read in Gower's book that the English approach to "capital" and to its reduction differed considerably from the American solution. ${ }^{47}$ Similarly, many an English or Australasian lawyer, whose course in commercial law postulated the wisdom of the registration of chattel securities, would have a rude awakening on discovering that the German system functions just as well as ours without any such requirements, and that German lawyers tend to be just as firmly opposed to filing as we are in support of it. A closer analysis shows that whether a given system adopts or dismisses registration is closely connected with the principles concerning the transfer of title to chattels. ${ }^{48}$ If the nemo dat quod non habet rule is subordinated to the protection of a bona fide purchaser or creditor who acquires a chattel or a security over it

For examples see the cases cited in (1978) 9 VUWLR at 447, n 14.

47 See, currently, 3 ed (London, 1969) 114 et seq.

48 See Angelo and Ellinger "Transitory Finance" (1973) 4 Journal of Maritime Law and Commerce 543. 
from a person who has the rightful possession, the need for registration is diminished. In this specific instance, as well as in the case of the comparison of some doctrines of company law, the research tends to suggest an approach to reform. It further indicates that some doctrines are not as fundamental as may be concluded from the study of a single system.

That comparative research is a good means for introducing new ideas into a legal system is obvious. The adoption of the Scandinavian institution of the Ombudsman in many Common Law jurisdictions is a classic example in point. ${ }^{49}$ Others are the extensive borrowings in other areas of administrative law, ${ }^{50}$ the possible influence which German law had on the Torrens system, ${ }^{51}$ and the wide adoption of consumer protection laws reflecting the American approach to the problem. ${ }^{52}$ In most of these instances law reformers, academic lawyers or politicians conducted a comparative study of foreign systems before proposing their own amendments to the laws of their own countries. We are, of course, not suggesting that the legislature in any given country is likely to adopt every foreign legal institution or doctrine which is shown to be superior to local law. Thus, it is typical that English law has retained the doctrine of consideration although several generations of lawyers have been aware that the Franco-German notion of causa creates fewer legal complications. ${ }^{53}$ National pride and the stronghold of tradition plays an important role in this type of case. Moreover lawyers' law, which is considered technical and stereotyped, is usually less given to reform than such areas as administrative law or industrial law, which are more closely related to politics.

Occasionally comparative research assists in distinguishing between what is fundamental and what is secondary in a given system. The fact that the doctrine of consideration has been retained in England despite a knowledge of the existence of

49 For a brief account of its travels from Northern Europe to New Zealand see Walter Gellhorn Ombudsmen and Others (Cambridge, Mass, 1967) 101-103 and the sources in nn 35 and 36.

50 For example the Judicature Amendment Act 1972 which was closely based on the Judicial Review Procedure Act 1971 of Ontario.

51 Whalan, DJ Origins of the Torrens Systems in the New Zealand Torrens System in G W Hinde (ed) The New Zealand Torrens System Centennial Essays (Wellington, 1971) 1, 6-7.

52 Note that many of the provisions of the Uniform Consumer Credit Code of the United States are reflected in the Consumer Credit Act 1974 (UK).

53 It would appear that Lord Mansfield was aware of the notion of causa; see, for example, Pillans $v$. Van Mierop (1765) 3 Burr 1663, in which he treated the doctrine of consideration as a rule of evidence. For an analysis, and a rejection of his view see Rann $v$ Hughes (1778) 7 TR 350n. The writings comparing consideration and causa, especially in the 20th century, are very substantial indeed. See, for example, von Mehren "Civil-Law Analogues to Consideration: An Exercise in Comparative Analysis" (1959) 72 Harv LR 1009, and Keyes "Cause and Consideration in Califomia - A Re-Appraisal" (1959) 47 Cal L R 74. 
alternative solutions, tends to suggest that it is fundamental to English law. It must, at the very same time, be conceded that many a doctrine which was considered basic at one time had to yield to the force of changing circumstances. The medieval prohibition of usury is a case in point.

Once it is shown, by the use of comparative research, that a certain rule or principle is common to many jurisdictions, it may, prima facie, be concluded that the rule or principle in question is basic or essential. The doctrine of property is an interesting illustration. It exists, under different names, in a surprising number of jurisdictions, either as a basic concept or as a facet of the sale of goods and of chattels securities. Even in communist countries, which had every right to regard it as a manifestation of capitalism, the doctrine was modified rather than abolished. ${ }^{54}$

One may, as a result, be inclined to think that it constitutes a fundamental or primary legal concept which is here to stay.

The same method can be used to shed light on more specialised problems. Thus, it is a well known principle of English law that a guarantee is binding on a surety only if he gives it to induce the creditor to extend the loan to the debtor or to grant him extra time for payment. If the guarantee is given after the extension of the loan, English law maintains that there is no consideration for it. ${ }^{55}$ Notably, a similar principle concerning guarantees is found in Continental systems, which explain it on the basis of causa. ${ }^{56}$ It was also a principle of Roman Law, ${ }^{57}$ and of classical Jewish law. ${ }^{58}$ One may, therefore, be inclined to conclude that the rule in question is essential to the law of suretyship.

A word of caution is, however, required. In many cases of this type the similarity between different legal systems results from the fact that the principle in question has permeated from a common origin. It is possible that the above mentioned principle of the law of suretyship is explicable on that basis. Roman law and classical Jewish law were subject

54 By way of illustration, note that the second book of the German Civil Code, which deals with the law of obligations, has been substantially retained in a number of communist countries including East Germany.

55 French $v$ French (1841) 2 M \& G 644; Astley Industrial Trust Ltd v Grimson Electric Tools (1965) 109 SJ 149; A G Guest (ed) Chitty on the Law of Contract (24th ed, London 1977) Vol II, s 4809.

56 In France for instance see Mazeaud Leçcons de droit civil vol II (3rd ed, Paris, 1966) 209, and Vol III (2nd ed, Paris, 1963) 18; also Starck Droit Civil - Obligations (Paris, 1972) 463.

57 See generally Buckland and McNair Roman Law and Common Law (2 ed, Cambridge, 1965) 221-236; Cuq Institutions juridiques des romains (2nd ed, Paris, 1904) ch XII; and in particular Lee Elements of Roman Law (4th ed, London, 1956) Book IV ch XVIII.

58 Baba Bathra, ch 10 , v 8. 
to cross fertilisation. Roman law had its influence on the law of medieval Europe, which in turn, had its own effect on English law. 59

It requires detailed research, coupled with inspired guesses, to analyse problems of this type. In particular, it is important to conduct comparative research of this type from both an analytical and an historical point of view. Sometimes the results may appear meagre. The work in question, though, has its own intellectual reward.

\section{TEACHING AND RESEARCH}

\section{A The General Connection Between Teaching and Research}

\section{Basic points}

The close connection between teaching and research has been the subject of a great deal of discussion. In particular, we wish to draw attention to the excellent paper, delivered in Christchurch in 1975, by our colleague and the then Dean the Law Faculty, Mr J C Thomas. ${ }^{60}$ We have decided not to traverse ground covered by him. We shall concentrate, in the next few pages, on the two major ways in which teaching is conducive to the production of new ideas. First, we believe that the hard work involved in preparing a course tends, on many occasions, to trigger off new approaches to the subject or original ideas about a specific legal problem. Secondly, it cannot be doubted that an active discussion in class and unexpected questions raised by students are a source of inspiration. In a sense this bears some similarity to an argument of a case by counsel before a gifted judge. Both tend to air a subject that might have become musty or stale. ${ }^{61}$

\section{Development of ideas while preparing a course}

Most law teachers find that the preparation of a course involves hard work. Usually one has to start by familiarising oneself with the entire subject. This is followed by a more detailed study of the topics to be covered in class. A good textbook is, of course, a great help. But the days in which a teacher came to class and read out a section from a book belong to a period happily gone by. Usually a teacher has to read a substantial number of cases and other materials in order to decide, for himself, what is to be used in his course. This process is, of course, essentially the same as research directed at publication. The teacher, like the researcher, has to have a general overview of the subject and a detailed

59 See, in particular, Scrutton The Influence of the Roman Law on the Law of England (Cambridge, 1885).

60 "A Modest Programme for the Improvement of Law Teaching" (1978) 9 VUWLR 405.

61 For an interesting illustration, see National Westminster Bank $v$ Barclays Bank International Ltd, supra n 30. 
knowledge of the particular area examined by him. He also requires the time needed to separate the significant and essential from the mundane.

This comparison shows that the preparation of a course ought to be, and usually is just as conducive to the production of new ideas as research leading to the writing of an article or to the preparation of an opinion needed for litigation.

Another benefit derived from the preparation of a course is that it induces the teacher to formulate his ideas in a systematic and comprehensible manner. Very few teachers are able to do justice to a subject while speaking off the cuff. ${ }^{62}$ The problem, in essence, is one of presentation. To be effective, a course requires the preparation of a clear structure and of a formulation of the specific ideas or concepts which are to be presented to the students. The same requisites are, of course, present in good research work. We do not overlook the fact that a teacher, like a barrister, is primarily concerned with oral presentation, which involves an element of public speaking, while a researcher prepares his materials for writing.

But the basic problem, faced alike by law teachers, by barristers and by writers, is how to use words most effectively in order to present a concept or to convey an idea. ${ }^{63}$

In our opinion, this very process is, in itself, a source of inspiration. Frequently, a new thought occurs while one is in the process of preparing a lecture or a case class. Indeed, the new idea may be triggered off by the lack of clarity in a sentence one is trying to polish up or by the difficulty in determining how to get a complex point across in class. We are convinced that experiences of this type are so common as to render examples superfluous. However, it is noteworthy that once again the source of the inspiration is the basic hard work involved.

An additional benefit to research, resulting from the teaching of a course in law, is to be found in the deeper knowledge of the subject gained over the years, a knowledge which is the outcome of experience, and which is not easily acquired when one is teaching a course for the first time. Admittedly, a single year of teaching can give a teacher a profound knowledge and an original insight into some specific topics highlighted in his course. But a general overview of a field - which is imperative for putting specific problems in their correct context - is rarely attained in a short period of time. It is significant that some of the most

62 Some teachers boast that they never give the same lecture twice as they produce their ideas whilst lecturing on the subject off the cuff. Students may be forgiven for frequently describing such lectures as discursive, puzzling and vague.

63 Some teachers in the field of jurisprudence appear to be unaware of the basic requirements while consistently remonstrating with judges and the so-called "black letter lawyers" for not making themselves clear. 
distinguished legal textbooks were written by academics who had had a number of years of teaching experience in the field. ${ }^{64}$ Indeed, an author's insight into a topic usually increases while he is studying it and writing it up. The point is easily proved when one compares an early edition of a textbook with a later one prepared by the same author. The first edition is frequently the most sparkling one; a later edition tends, however, to reflect the author's deeper understanding of the subject. ${ }^{65}$ Naturally, we are not suggesting that experience is by itself an adequate quality for either teaching or research. A teacher who repeats a course from year to year without re-thinking it, or a writer who updates new editions of his book without re-examining his entire treatment of the subject, faces the danger of the "hardening of the intellectual arteries". Undoubtedly, a book may be so good as not to require fundamental changes. Similarly, a course may be of such a high standard as to admit no substantial alterations. But in most cases the imperfections of both legal courses and legal publications are made apparent by means of a good discussion in class or from a rough treatment by another scholar.

\section{Ideas produced in class}

Very few teachers are able to boast that none of their ideas were the outcome of a class discussion. Actually, the majority would be proud to concede the benefit they had derived. This is not to suggest that such teachers have stolen their students' ideas. Indeed, the idea itself might not have been clearly formulated by the student to whom one feels indebted. In some cases, it might have been triggered off by a question which appeared foolish at first sight. Equally, the teacher might have been put on the right track by a controversial or even by an apparently unacceptable argument. We believe that a few examples from our own experience may be of interest.

An instance demonstrating the usefulness of an apparently foolish question is provided by the experience of one of us in his first course on banking law. The question related to the action in conversion which the "true owner" of a cheque can bring against a collecting bank. For the purposes of such an action, the cheque is treated as a type of chattel and the amount recoverable, according to leading textbooks and cases, is equal to its face value. ${ }^{66}$ One student asked whether a cheque would be regarded as retaining its face value even if it were stopped by the drawer. When put in this way, the question appeared silly. The countermand of a cheque does not preclude a holder in due course from enforcing it against

Salmond on jurisprudence is, we believe, a good example in point.

Paget The Law of Banking (4th ed, London, 1930) is a good example.

66 A G Guest (ed) Chitty on the Law of Contract (24th ed, London, 1977) Vol II, s 2575 and authorities cited there. 
the drawer and from recovering from him the full amount. ${ }^{67}$ As this specific point had been covered in the previous class, the teacher was sufficiently incensed to rubbish the student. The significance of the point became apparent only when the question was raised in a different manner and context in the next year. On this occasion, another student asked: "Why should the 'true owner' of a cheque, such as an employer whose cheque had been forged by an employee, be permitted to claim at one and the same time that the cheque was a forgery and hence a nullity but that its 'value' for the purposes of an action in conversion was the amount inscribed by the rogue". This was a new way of looking at the very question raised by the first student. A study of case law revealed an authority which held that a forged cheque was a nullity and hence worth no more than the piece of paper on which it had been written. ${ }^{68}$ Obviously, here there was an exception to the rule that a cheque's value was the amount appearing on its face. Had the teacher in question been more patient with the first student, he might have discerned the importance of the apparently foolish question there and then.

"Foolish arguments" may, on occasions, be just as useful as "silly questions". By way of illustration we propose to use a point which crops up in most courses within the field of commercial and common law. Every now and then a student argues that a certain party to a dispute ought to be refused judgment because this party would find it easier to bear the loss than the other. The point is usually raised when one party - the suggested loser - is an insurance company, a bank, a shipping line or any other type of large and wealthy corporation. ${ }^{69}$ Basically, the argument is sadly lacking in merit. A means test is a poor criterion for dispensing justice within the private law areas of capitalist systems. A closer examination of the law student's proposed means test shows, however, that, with but one modification, it can become convincing. Instead of suggesting that judgment be entered against the party most capable of bearing the loss, it is possible to argue that the loss fall on the party that is in the best position to insure against it. This proposition can be supported on the basis of imposing on that party a duty of care, or a duty to foresee the loss and to effect cover. This argument, which is currently advocated in certain quarters, ${ }^{70}$ leads to results similar to those of the somewhat naive means test. In effect, that emotive suggestion helps pave the way for the arguable and, to us, quite logical proposition.

67 Bills of Exchange Act 1882 (UK), s 55.

68

69

70

New Zealand, under which the state effectively provides compensation - cover - against accident injuries. 
Our examples tend to show that even the strangest or apparently silliest questions and arguments can on occasions be the source of a novel approach. This applies, a fortiori, where a point raised in class is controversial or questionable rather than absurd. The golden rule in all these situations is not to dismiss an argument too lightly and, in particular, not be concerned if it tends to disprove one's own theory. The merit of all legal argument lies in its potential for driving holes in the armour of conventional wisdom, a wisdom that may have been accepted for a long time because nobody has bothered to question it. The price which one has to pay - that of being occasionally proved wrong in class - is, by comparison, a very small one.

Undoubtedly, the ability to recognise a good argument or a useful question is, again, one of inspiration or of intuition. Moreover, it would be wrong to deny that frequently its recognition is a matter of luck. It all depends on how the point is raised, on the context in which it is being argued and on the group or class with whom it is being discussed. The clear advantage of a point being argued out in a forum is, however, beyond question. In the final analysis, a discussion in class differs only in degree, but not in nature, from the pursuit of a legal point before a judge or its argumentation among a group of experienced lawyers.

\section{B Honours and Masters Courses}

A specific illustration of how teaching can aid research is to be found in honours and masters courses at Victoria University. These courses involve a number of students in original research. It may take several forms:

(a) research papers done in lieu of the examinations in an LLM subject (there were about 37 such papers prepared in 6 classes in 1977);

(b) the piece of legal writing required of LLB Honours students (about 20 each year);

(c) theses for LLM (usually 2 or 3 each year); and

(d) papers prepared for the seminars for LLB Honours (usually 1 by each student for each seminar subject) and for LLM (usually 2 by each student for each seminar subject).

The supervision of this research can, of course, be of enormous benefit to the teacher both for his teaching and for his own research. ${ }^{71}$ But even greater is - or should be - its

71 So, to take the interests of one of us, consider (1) the legal writing done for the LLB Honours degree by Glenese J Adams on "The Nelson Cotton Mill Agreement - a lesson from 1960 for 1978" (1978) 9 VUWLR 465, D K Clifford on "The Scientist and Freedom of Information" (1978) 9 VUWLR 145, and G J van Bohemen on "New Zealand Planning Council" (1978) 9 VUWLR 185; and (2) the research papers done for an LLM subject by R McInnes on "Jurisdictional Review after Anisminic" (1977) 9 VUWLR 37 - and by Marian Lucas on "The Land Settlement Board" Margaret Lee on "The Human Rights Commission Bill - a Case Study in Legislative Influence" by 
value for the students involved. Over a period of one to three or even more years they should progress through increasingly difficult research projects. They should build on the basic research and writing skills developed in the early years of the law degree and acquire some of the techniques discussed in this paper. The seminars themselves can also have advantages in terms of suggesting new ideas and testing old ones that are indicated in the preceding section. Indeed the strength of the classes, their size, their organisation and the advanced level of the subjects should ensure that those advantages flow much more frequently than in the undergraduate courses.

\section{USE OF RESEARCH}

Every now and then a legal practitioner scoffs at a publication of an academic. Occasionally, he demonstrates it to be lacking in accuracy or in judgment. In other instances, the complaint is that the work is "too academic" or, in other words, not sufficiently useful from the practitioner's point of view. We have no quarrel with the first type of criticism. A book or an article which is unsound is a fair subject of castigation both by academics and by colleagues at the Bar. It is the second argument which, to us, is a source of concern. It is answerable on two levels. The first is to assert, openly, that utility is not the only yardstick for the value of research. The seçond is to highlight the many instances in which research conducted by academic lawyers has proved of great value to legal practitioners. We propose to pursue both points.

There is a certain hollowness in the argument that a piece of research is "too academic". In essence, the person who raises it questions the value of the pursuit of pure knowledge. This attitude is just as narrow as the opposite stand, taken by some Greek philosophers, who were opposed to any attempt to acquire knowledge for a mere utilitarian purpose. ${ }^{72}$ In real life, it is usually hard to tell whether or not a given piece of research may turn out to be "useful". The world of science abounds with good examples. In the field of law, the works of F W Maitland are right in point. At first glance, his studies in legal history appear totally removed from the every day practice of a lawyer. They have, however, shed new light on an obscure doctrine and, one suspects, have often assisted gifted counsel to question the established view of the day. After all, who can wholeheartedly support an obscure principle of procedure once it is shown to have been entrenched as the result of a sheer error in an obsolete text? Moreover, Maitland's work is important in yet another way. It enables

David G Dunbar on "Alice in Wonderland: The Law of Statutory Standing", by Garnet Crowhen on "An Interim Remedy in New Zealand Administrative Law" and by Adrienne von Tunzelmann on "The Legislature and the Control of Commercial Practices and Prices" (all unpublished VUW LLM research papers 1978).

72 Note that the drive for utility in research is, nowadays, voiced in many public attacks on universities. 
a bright student to gain a better comprehension of the Common Law system in which he practises.

Gower's Modern Company Law is another example in point. A generation of lawyers brought up with it has been more ready than their predecessors to challenge the antiquated Victorian doctrines of company law. An anecdote concerning this tends to show the true merit of the "too academic" argument. We are told, on, good authority, that this was the very ground which induced a certain law society - for a considerable number of years - to refuse to acquire this book for its collection. When the book was finally purchased, it was abducted by an unknown practitioner within a few days of its arrival never to be seen again. A replacement copy met with a similar fate. One wonders whether busy lawyers, who found a "borrowed" book unuseful, would have decided to retain it for an indefinite period of time!

Another function of research is that it can lead to developments within a given branch of law and, in some instances, may be of direct use for legislative law reform. It is significant that the modern systematic analysis of the law of contract owes much to the first edition of Anson; ${ }^{73}$ one only has to compare it with earlier treatises in the field. ${ }^{74}$ Equally it is difficult to overestimate the importance of de Smith's Judicial Review of Administrative Action in bringing together for the first time in a comprehensive way the enormous range of material constituting administrative law and in systematising that subject. ${ }^{75}$ The successful assault in the United States on the doctrine of privity of contract, which constituted an obstacle to the development of a doctrine of products liability, owes as much to the writings

73 Anson's Principles of the Law of Contract appeared, in its first edition, in 1867.

74 Such as Leake $A$ Digest of the Principles of the Law of Contract (London, 1867) or Addison $A$ Treatise on the Law of Contract (5 ed, London, 1862).

75 See for example the tribute paid by Wade: "All who have worked on this subject are united in their gratitude to the late Professor de Smith for his pioneering work, Judicial Review of Administrative Action. Although I have occasionally joined issue with his conclusions, I have more frequently admired his achievement." Administrative Law (4 ed, 1977) vi. 
of Dean Prosser as to the judgments of Traynor J. ${ }^{76}$ One measure of this role of academic writing is what appears to us to be a marked increase in recent years in its citation in argument and judgments. ${ }^{77}$

Moreover, articles and monographs written by academics have on many occasions been of assistance to law reform agencies. The frequency with which they are cited in reports of committees is too well known to require specific reference.

\section{CONCLUSION}

Our conclusion, thus, is that good research work has its place regardless of its immediate utilitarian effect. The main question is not its academic or practical orientation, but its soundness, its thoroughness and its inspiration.

76 For an excellent account, highlighting the influence of Dean Prosser and of Traynor J, see Tobin "Products Liability: A United States Commonwealth Comparative Survey" (1969) 3 NZULR 377 and "Products Liability: Recovery of Economic Loss" (1970) 4 NZULR 36.

77 It would be a major exercise - which, to our knowledge, no one has yet attempted fully to document this point (which seems to parallel changing judicial styles, especially in the House of Lords) but for examples from three quite different areas see Miliangos $v$ Frank (Textiles) Ltd [1976] AC 443, Trendtex Trading Corporation $v$ Central Bank of Nigeria [1977] QB 529, (CA) and DPP $v$ Majewski [1977] AC 443. 